\title{
Hvorfor måle hvilepulsen?
}

Engelsk oversettelse på www.tidsskriftet.no

Dødeligheten av hjerte- og karsykdommer har sunket, men disse sykdommene eksisterer fortsatt. Nesten halvparten av alle tilfeller av hjerteinfarkt rammer personer som ikke tidligere har hatt hjerteog karsykdom, selv om disse har en lavere totalrisiko enn de som er diagnostisert med slik sykdom (1). Epidemiologiske undersøkelser tyder på at telling av hvilepuls kan benyttes til å bestemme fremtidige risikoforhold i befolkningen (2). Den prognostiske betydningen av denne enkleste av alle hjerte-kar-variabler blir imidlertid vanligvis oversett.

I dette nummer av Tidsskriftet argumenterer Dalby \& Gjesdal (3) for at man bør legge mer vekt på pulsen og for at pulstelling bør inngå i vanlige kliniske konsultasjoner. I dag kontrollerer man pulsen bare hos bestemte undergrupper, for eksempel pasienter med hjertefeil eller sykdommer i kransarteriene (4). Registrering av puls i befolkningen kan imidlertid bli et tilleggsverktøy for predikering og kontroll av hjertesykdommer. Pulsmåling kan derfor benyttes som en viktig prognostisk markør for både primær- og sekundærforebygging.

Varig forhøyet hvilepuls gir økt risiko for blodtrykksstigning og er forbundet med forstyrrelser i stoffskiftet. Dette bidrar også til utvikling og forverring av koronar aterosklerose, øker sannsynligheten for destabilisering av plakk og gir opphav til arytmier, som kan føre til akutt hjerteinfarkt og brå død $(2,4,5)$.

Bruken av pulsen som en klinisk variabel har store fordeler: Kostnadene er lave og kontrollen tar liten tid. Dette er et enkelt mål som er lett å forstå for de fleste, det gjør det anvendbart for klinikere $\mathrm{i}$ involveringen av pasienter $\mathrm{i}$ ivaretakelsen av egen helse. Videre kan pulsendringer over tid gi tilleggsinformasjon om hjertets tilstand. Selv om forhøyet puls er en selvstendig prediktor for dødelighet, kan det i tillegg være en indikasjon på andre kardiovaskulære risikofaktorer. Mulige sekundære årsaker til forhøyet puls, for eksempel hypoksemi, anemi og medikamentbruk, bør derfor også tas i betraktning.

Klinikere bør telle pulsen når de måler blodtrykket og følge samme fremgangsmåte (2). Puls over 80 slag i minuttet bør få alarmklokkene til å ringe. Hva er så de første skritt som bør tas når høy hvilepuls er observert? Foreskriving av fysisk trening er åpenbart et mulig tiltak. Som Dalby \& Gjesdal skriver har variabilitet i hvilepuls forbundet med fysisk trening fått stor tilslutning i de senere år $(4,5)$. Autonome effekter som følge av trening (økning i parasympatisk aktivitet og nedgang i sympatisk aktivitet), koblet til en mulig reduksjon av normal hjerterytme, gir lavere hvilepuls. Treningsintensiteten kan tilpasses individuelt. Gjeldende retningslinjer anbefaler trening med høy intensitet (sykling, løping, skigåing) i minst 30 minutter to til tre ganger ukentlig eller trening med lav intensitet (rask gange, jogging) i minst 30 minutter hver dag. Ytterligere forskning er nødvendig for å vurdere de relative virkningene av treningsintensitet på endringer i hjerterytmen.

Andre faktorer som kan påvirke hvilepulsen over tid omfatter medikamenter, kosthold, mental tilstand og samspillet mellom genetiske forhold og miljøet. I henhold til Dalby \& Gjesdal bør en balansert risikostyring av forhøyet hvilepuls rettes mot endringer i livsstil med et program for regelmessig aerobisk trening og kostholdsveiledning, eventuelt rasjonell atferdsterapi med sikte på å unngå kronisk stress eller depresjon.

De fleste data om sammenhengen mellom hvilepuls og dødelighet i befolkningen generelt stammer fra epidemiologiske studier. Én mulig årsak til legenes motstand mot å bruke pulsen som en gyldig risikofaktor for hjerte- og karsykdommer er de metodologiske problemene som er forbundet med befolkningsstudier. Ikke desto mindre har epidemiologiske undersøkelser over tid banet veien for konvertering av resultater innen grunnforskning til vellykkede helsetiltak. En puls på over 80 slag i minuttet kan kanskje betraktes som et faremoment $\mathrm{i}$ befolkningen som helhet, men bør vi behandle den like ekstensivt som andre risikofaktorer forbundet med hjertet og stoffskiftet, slik som fedme, røyking, forhøyede kolesterolverdier eller høyt blodtrykk?

Det finnes overbevisende belegg fra studier for at hjerterytmen er direkte knyttet til forhøyet risiko, i tillegg til å være en markør for en underliggende sykelig forstyrrelse. Pulstelling er enkelt, og en serieundersøkelse av hvilepulsen kan brukes som en viktig prognostisk markør for generell dødelighet og for dødelighet av hjerteog karsykdommer. Behandling av høy hvilepuls hos friske personer uten sykdomshistorie synes å være overdrevet, men ikke desto mindre antyder data fra litteraturen at man bør anbefale regelmessig fysisk aktivitet for symptomfrie personer med høy hvilepuls som kan dra nytte av tiltak for primærforebygging.

\section{Javaid Nauman}

javaid.nauman@ntnu.no

Javaid Nauman er postdoktor ved Cardiac Exercise Research Group (CERG). Hans forskningsområder er hjerte- og karsykdom, trening, kardiovaskulær epidemiologi og genetikk.

Forfatter har fylt ut ICMJE-skjemaet og oppgir ingen interessekonflikter.

\section{Litteratur}

1. Kerr AJ, Broad J, Wells $S$ et al. Should the first priority in cardiovascular risk management be those with prior cardiovascular disease? Heart 2009; 95: 125-9.

2. Palatini P. Elevated heart rate in cardiovascular diseases: a target for treatment? Prog Cardiovasc Dis 2009; 52: 46-60.

3. Dalby M, Gjesdal K. Hva sier hvilepulsen om helse og sykdom? Tidsskr Nor Legeforen 2012; 132: 1348-51.

4. Cook S, Togni M, Schaub MC et al. High heart rate: a cardiovascular risk factor? Eur Heart J 2006: 27: 2387-93.

5. Fox K, Borer JS, Camm AJ et al. Resting heart rate in cardiovascular disease. J Am Coll Cardiol 2007; 50: 823-30. 